\title{
ASTEROLINON LINUM-STELLATUM (PRIMULACEAE) IN HUNGARY
}

\author{
Z. BARINA and D. PIFKó \\ Department of Botany, Hungarian Natural History Museum, \\ H-1476 Budapest,.Pf. 222, Hungary; barina@bot.nhmus.hu,pifko@bot.nhmus.hu
}

\begin{abstract}
The first report of Asterolinon linum-stellatum from Hungary is provided, based on a specimen that was collected by Gyula Tauscher at Tarnaörs (North Hungary) in 1863, and its voucher was recently found in the BP herbarium. There is little chance of erroneous labelling, or accidental introduction of the species, thus the specimen most likely represents a small native outlying population several hundred kilometres from the continuous distribution of the species. The natural habitats of the Tarnaörs region had been completely destroyed over a hundred years ago and in lack of a subsequent confirmation of the plant's occurrence, the taxon should be treated as an extinct member of the Hungarian flora.
\end{abstract}

Key words: Great Hungarian Plain, Gyula Tauscher, new record, vascular plants

\section{INTRODUCTION}

With only a very few species described in this genus, Asterolinon is closely related to Lysimachia (MARTins et al. 2003). Asterolinon linum-stellatum (L.) Duby is distributed over a large area encompassing the Mediterranean regions of South Europe, North Africa and the Middle East. It has become introduced into South Australia, where it is naturalised in rocky outcrops (BARKER et al. 2005). It is a rare alien in Europe outside its native circum-Mediterranean area (in Belgium: Verloove 2006, DAISIE 2009).

There is no mention of the species in Hungarian flora works (KIRÁLY 2009, SimON 1992, 2000), and has no records from the current territory of the country (JÁVORKa 1925).

\section{RESULTS}

In the Herbarium Carpato-Pannonicum of the Hungarian Natural History Museum (BP), one specimen of Asterolinon linum-stellatum has been found (BP 715087). It was collected by Gyula Tauscher at Tarnaörs (Heves county, North Hungary) on 5th May 1863, and labelled as "Hungaria. Comitatus Heves. - E pascuis arenosis siccis prope Tarna Eörs", with the handwriting of Tauscher. The herbarium specimen includes 7 plants with mature fruits. 
The specimen was correctly determined by Tauscher, but was never published (similarly to most of his records). Tauscher, one of the greatest collectors in Hungary, worked in Tarnaörs as a physician in 1863 and 1864 (BARNA 2006). At that time Tarnaörs was located near the main transport route of the region, and there was an estate of the Orczy family with a large pheasant hunting area (SCHMOTZER 2014) (Fig. 1).

\section{DISCUSSION}

Tauscher collected a number of rare, and currently missing, taxa from the surroundings of the village (SCHMOTZER 2014), one of these could be Asterolinon. Previously, he was within the known range of Asterolinon linum-stellatum only when he had to be in service during the Second Italian War of Independence in 1859. According to his biography, he had no later possibility to collect this plant in the Mediterranean; however, he received a number of herbarium specimens as exchange from contemporary botanists (BARNA 2006).

The occurrence of Asterolinon linum-stellatum in Hungary is vouchered only with a single herbarium specimen, collected by Gyula Tauscher at Tarnaörs ( $\mathrm{N}$ Hungary) in 1863. The locality is far from the continuous range of distribution of the species (the nearest known localities are in Croatia, from ca $500 \mathrm{~km}$ of Tarnaörs), and has quite different climate (mainly continental, instead of Mediterranean). As there are no additional records of the species from the region or even from Hungary, the reliability of the record may raise questions of verification.

Tauscher had tens of thousands of herbarium specimens received in exchange (BARNA 2006); however, this period occurred after he moved from Tarnaörs. The origin of Asterolinon from exchange material and its mislabelling to Tarnaörs is conceivable only if he had labelled the specimen (much) later, when he already had samples of Asterolinon from exchange. Yet no other specimens of Asterolinon can be found in the material of Tauscher at our BP Herbarium Carpato-Pannonicum. Since Tauscher was a qualified botanist and a precise collector, thus it is highly improbable that he mixed up an exchange specimen with one that was collected in Tarnaörs by him. Tauscher, as an eminent botanist, had contributed a number of significant records, perhaps the most interesting of them being Nepeta parviflora M. Bieb. in Mezőföld (Central Hungary); however, this record, and even the occurrence of the species, was left out from the Hungarian flora until a recent confirmation by LENDVAI (1993). On the contrary, it should be noted that there is a databased record of Seseli leucospermum W. et K. from Tarnaörs by Tauscher (BP 226793), which is surely erroneous as the plant is endemic to the dolomite regions of North-Central Hungary and could have 


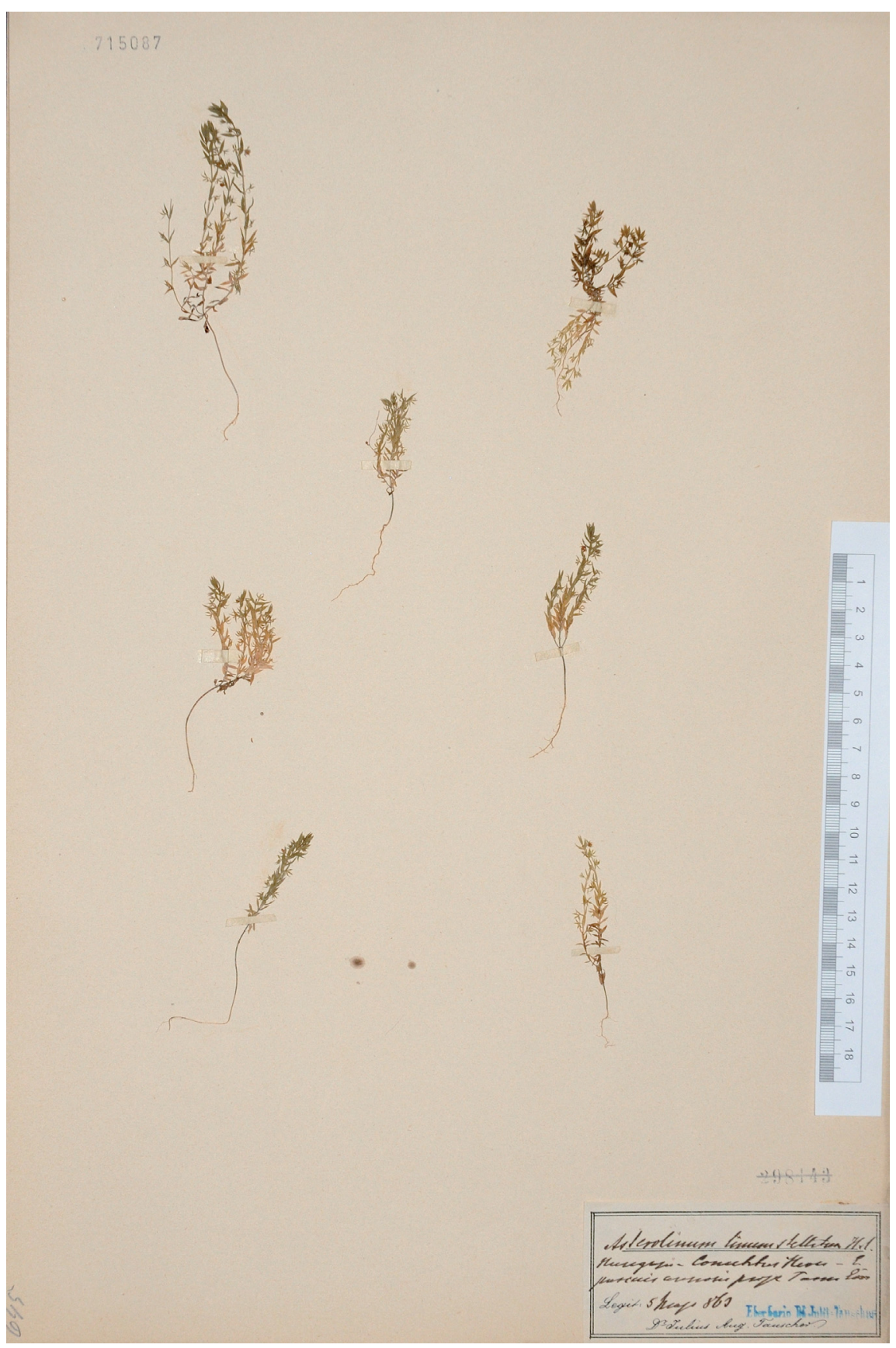

Fig. 1. Voucher specimen of Asterolinon linum-stellatum (L.) Duby, collected by Gyula Tauscher in Tarnaörs, Hungary (BP 715087) (photo: Balázs Pintér). 
never occurred in the Great Hungarian Plain, well outside its spontaneous area and without any suitable bedrock outcrop (KUN 1998).

The sandy areas around Tarnaörs could have habitats similar to those of Asterolinon linum-stellatum along the Adriatic coast. It is not without a precedent, that some species of the Mediterranean coastal sand dunes appear also in the sandy areas of the Great Hungarian Plain (e.g. Alkanna tinctoria) showing a large gap in their distribution. All naturally sandy habitats in the Tarnaörs region were unfortunately destroyed at around the beginning of the 20th century, thus a number of notable species collected there previously by Tauscher were also wiped out, such as Fritillaria meleagris L., Polygala major Jacq., Astragalus dasyanthus Pall., Plantago maxima Juss. ex Jacq. None of these have later confirmations (SCHмOTZER 2014) or even previous reports, similarly to Asterolinon linum-stellatum.

Accidental introductions of plants, i.e. via transport or other "attached introduction", in the middle of the 19th century in Hungary were far more limited than in recent times. Thus the spontaneous occurrence of Asterolinon linumstellatum at Tarnaörs may be safely assumed. This could be similar to the spontaneous presence of Ophrys bertolonii Moretti, another Mediterranean species, recently showed in the Great Hungarian Plain (Molnár et al. 2011).

Consequently, Asterolinon linum-stellatum seems to be a "justified" member of the Hungarian flora, and there are no serious reasons to discredit the reliability of the herbarium voucher. Since around Tarnaörs could have been similar habitats where the species could naturally occur, and that the accidental introduction of plant species' was a rare event at the middle of the 19th century, the possible (human-induced) introduction of the species is unlikely. However, we can speculate on that Asterolinon linum-stellatum was not a permanent member of the Hungarian flora, but appeared only temporarily under suitable environmental conditions. As the naturally sandy habitats were all destroyed in the region, and the occurrence of Asterolinon linum-stellatum from the same region (and generally, from Hungary) has not been confirmed to date, the plant should be treated as extinct from Hungary.

\footnotetext{
Acknowledgement - We would like to thank András Schmotzer for his valuable comments on the manuscript.
}

\section{REFERENCES}

BARker, B., BARker, R., Jessop, J. and Vonow, H. (2005): Census of South Australian vascular plants. - Botanic Gardens of Adelaide \& State Herbarium, Adelaide, 397 pp. 
BARnA, Zs. (2006): Tauscher Gyula Ágoston - egy alig ismert botanikus emlékezete. (In memoriam of a hardly known botanist Gyula Ágoston). - Bot. Közlem. 93(1-2): 17-25.

DAISIE (Delivering Alien Invasive Species Inventories for Europe) (2009): Handbook of alien species in Europe. Invading nature. - Springer, Dordrecht, 399 pp.

JÁvor Ka S. (1925): Magyar Flóra. [Flora Hungarica]. - Stúdium, Budapest, 1307 pp.

KirÁly, G. (ed.) (2009): Új magyar füvészkönyv. Magyarország hajtásos növényei. Határozókulcsok. (New Hungarian Herbal. The vascular plants of Hungary. Identification key). - Aggteleki Nemzeti Park Igazgatóság, Jósvafö, 616 pp.

Kun, A. (1998): Sziklai növénytársulások az Érd-Tétényi-fennsíkon. (Rocky plant associations on the Érd-Tétényi Plateau). - Kitaibelia 3(1): 65-70.

LENDVAI, G. (1993): Régi-új elem a magyar flórában: a borzas macskamenta (Nepeta parviflora M. Bieb.). (An old-new member of the Hungarian flora: Nepeta parviflora M. Bieb.). - Bot. Közlem. 80: 99-102.

Martins, L., Oberprieler, C. and Hellwig, F. H. (2003): A phylogenetic analysis of Primulaceae s.l. based on internal transcribed spacer (ITS) DNA sequence data. - Plant Syst. Evol. 237: 75-85. http://dx.doi.org/10.1007/s00606-002-0258-1

MolnÁr, V. A., MÁtÉ, A. and SRAMKó, G. (2011): An unexpected new record of the Mediterranean orchid, Ophrys bertolonii (Orchidaceae) in Central Europe. - Biologia 66(5): 778-782. http://dx.doi.org/10.2478/s11756-011-0086-2

Schmotzer, A. (2014): A Hevesi-sík flórakutatásának eredményei. (Results of the floristic surveys on Heves Plain). - In: Schmotzer, A. (ed.): Szikfok - dél-hevesi tanulmányok. Bükki Nemzeti Park Igazgatóság, Eger, pp. 25-68.

Simon, T. (1992): A magyarországi edényes flóra határozója. Harasztok-virágos növények. [Field guide to the vascular flora of Hungary]. - Tankönyvkiadó, Budapest, $892 \mathrm{pp}$.

Simon, T. (2000): A magyarországi edényes flóra határozója. Harasztok-virágos növények. [Field guide to the vascular flora of Hungary]. - Nemzeti Tankönyvkiadó, Budapest, 976 pp.

Verloove, F. (2006): Catalogue of neophytes in Belgium (1800-2005). (Scripta Botanica Belgica, 39). - National Botanic Garden of Belgium, Meise, 89 pp. 